\section{Evaluation of a Light-activated Nanoparticle Formulation of Titanium Dioxide with Zinc for Management of Bacterial Leaf Spot on Rosa 'Noare'}

\author{
Mathews L. Paret ${ }^{1}$ \\ University of Florida, North Florida Research and Education Center, 155 \\ Research Road, Quincy, FL 32351
}

\author{
Aaron J. Palmateer \\ University of Florida, Tropical Research and Education Center, Homestead, \\ FL 33031
}

\author{
Gary W. Knox \\ University of Florida, North Florida Research and Education Center, 155 \\ Research Road, Quincy, FL 32351
}

Additional index words. Xanthomonas sp., nanotechnology, bacterial disease management, ornamental crops, Rosa spp.

\begin{abstract}
Bacterial leaf spot on roses caused by a Xanthomonas sp. is a new disease affecting commercial rose production with the potential to cause major economic losses. In the past few decades, antimicrobial photocatalyst technology has emerged from basic research and development to provide convenient formulations of titanium dioxide $\left(\mathrm{TiO}_{2}\right)$ nanoparticles, which have the ability to destroy bacteria on surfaces in the presence of light. In this study, a $\mathrm{TiO}_{2}$ nanoparticle formulation containing zinc $\left(\mathrm{TiO}_{2} / \mathrm{Zn}\right)$ was tested for management of bacterial leaf spot on Rosa 'Noare'. $\mathrm{TiO}_{2} / \mathrm{Zn}$ caused significant reduction in the survival of Xanthomonas sp. strain $\mathrm{Xr}-1$ on glass coverslips coated with the nanoparticles on exposure to light at $3 \times 10^{4}$ lux for 10 minutes. There was no reduction of bacterial viability in non-coated or non-illuminated controls. Field applications of $\mathrm{TiO}_{2} / \mathrm{Zn}$ at $\approx \mathbf{5 0 0}$ to $800 \mathrm{ppm}$ on Rosa 'Noare' significantly reduced bacterial spot severity compared with the untreated control. $\mathrm{TiO}_{2} / \mathrm{Zn}$ activity was better or on par with the ornamental industry standard for management of rose diseases.
\end{abstract}

Roses are economically important ornamental plants in the United States and contribute substantially to the ornamental horticulture sector. The wholesale value of potted roses in the United States, sold as florist roses for indoor and patio use, accounts for more than seven million pots with a value of $\$ 23$ million

Received for publication 9 Oct. 2012. Accepted for publication 19 Dec. 2012

This research was conducted using funding from the Florida Nursery Growers and Landscape Association 2011-12.

We acknowledge the support of Stewart Chandler, Plant Protection Coach, Monrovia, Cairo, GA, for providing the plants for all the experiments at all locations and for providing nursery space for conducting experiments. Our sincere appreciation to Laura Ritchie, Biological Scientist, NFREC, Quincy; Hank Dankers, Plant Disease Diagnostician at Plant Diagnostic Clinic, NFREC, Quincy; Ian Maguire, Biological Scientist at TREC, Homestead; and Patricia Lopez, Laboratory Technician, TREC, Homestead, for technical support in conducting field trials. The nanoparticle formulation for this research was developed and supplied by Devron Averett and Stewart Averett, EcoActive Surfaces, Inc., Pompano Beach, FL.

${ }^{1}$ To whom reprint requests should be addressed; e-mail paret@ufl.edu.
(NASS, 2012), Roses sold as cut flowers account for more than $\$ 17$ million (NASS, 2012). The wholesale value of roses sold as deciduous shrubs is more than $\$ 194$ million (USDA, 2010). Among the many diseases reported on roses, bacterial leaf spot caused by Xanthomonas sp. is a relatively new disease affecting nursery production. The disease is widespread and documented in Florida on the shrub rose varieties 'RADrazz' $\left(\right.$ Knock Out $\left.^{\circledR}\right)$ and 'RADtco' (Double Knock Out $^{\circledR}$ ) (Vallad, 2009). This disease causes chlorotic and necrotic spots on the foliage rendering the plants unmarketable (Fig. 1). Florida's high relative humidity of greater than $75 \%$ throughout the growing season provides a favorable condition for the development of the disease and the spread of Xanthomonas sp. on roses.

Most commercial nurseries use overhead irrigation for rose production that further contributes to disease incidence and spread. There is currently no available information on best management practices for bacterial leaf spot on roses. Copper bactericides may provide control as in the case of other bacterial diseases, although copper tolerance in Xanthomonas spp. is common (Canteros, 2002; Pernezny et al., 2008; Ritchie and Dittapongpitch, 1991). We currently have no information on copper tolerance or resistance of rose strains of Xanthomonas sp. The current nursery plant disease management plan involves use of fungicides/bactericide rotations for management of black spot, Cercospora leaf spot, and bacterial leaf spot. This rotation plan includes the use of azoxystrobin, mancozeb, thiophanate methyl, and copper hydroxide-based chemistries in rotation at 7- or 14-d intervals depending on existing weather conditions from early spring to late fall (Stewart Chandler, Monrovia, personal communication). Current studies by our group and other groups in Florida are evaluating fungicide/bactericide rotation options for management of bacterial leaf spot on roses. Preliminary studies on the use of Acibenzolar-S-methyl, a systemic acquired resistance (SAR) inducer, that activates plant defense systems by increasing the transcription of stress-related genes indicate its ability to reduce bacterial leaf spot severity (Vallad, 2009).

A new area of our focus is exploring the possibility of using light-activated antimicrobials for management of bacterial leaf spot on roses. Antimicrobial photocatalyst technology has emerged from basic research and development to the application level in engineering and medicine with the development of $\mathrm{TiO}_{2}$ nanoparticles (Chen and Mao, 2007; Matsunaga et al., 1985). In the presence of light, $\mathrm{TiO}_{2}$ nanoparticles create highly chemically reactive hydroxyl and superoxide free radicals, which are detrimental to bacterial cells. This photocatalytic process continues as long as sufficiently energetic light is available. Although $\mathrm{TiO}_{2}$ nanoparticles have antimicrobial properties, using different doped (materials inside the $\mathrm{TiO}_{2}$ structure) versions of $\mathrm{TiO}_{2}$ with $\mathrm{Zn}$, silver, and copper can further enhance the functional properties (Colon et al., 2006; Namiki et al., 2005). Research studies have shown the antimicrobial potential of $\mathrm{TiO}_{2}$ nanoparticles on bacteria, fungi, and viruses (Adams et al., 2006; Anpo, 2000; Choi et al., 2009; Dancer, 2008; Page et al., 2009; Tsuang et al., 2008; Wu et al., 2010). A recent study demonstrated the effectiveness of applying macroparticle $\mathrm{TiO}_{2}$ as a foliar spray against bacterial blight of geranium and bacterial leaf spot of poinsettia caused by $X$. hortorum pv. pelargonii and $X$. axonopodis pv. poinsettiicola, respectively (Norman and Chen, 2011). That study indicated that a key limitation in the commercialization of macroparticle $\mathrm{TiO}_{2}$ was the higher level of white residue that remained on leaves after application, subsequently reducing the marketability of plants for ornamental use. Also, a large quantity of material may have to be used for effective disease control, which is not a sustainable approach. Also, $\mathrm{TiO}_{2}$ photocatalysts have been previously shown to have antifungal activity and yield improvement potential in many crops $(\mathrm{Lu}$ et al., 2006; Owolade and Ogulenti, 2008).

The objective of this study was to evaluate the photocatalytic effect of a $\mathrm{TiO}_{2} / \mathrm{Zn}$ nanoparticle formulation on a Xanthomonas sp. infecting roses and the impact of foliar 
applications on bacterial leaf spot. We hypothesize that the $\mathrm{TiO}_{2} / \mathrm{Zn}$ nanoparticle formulations may offer high bactericidal action in the presence of light and high efficacy in reducing bacterial leaf spot severity than the currently available industry practice.

\section{Materials and Methods}

Nanoparticle formulation, synthesis, and properties. The nanoparticle formulation used in this study is $\mathrm{TiO}_{2} / \mathrm{Zn}$ ( $7 \mathrm{~nm}$ average particle size; anatase crystal structure; 5000 to $8000 \mathrm{ppm} \mathrm{TiO}_{2}$, and 50 to $75 \mathrm{ppm} \mathrm{Zn}$ as active ingredient; EcoActive Surfaces, Inc., Pompano Beach, FL).

In vitro photocatalytic activity of $\mathrm{TiO}_{2} / \mathrm{Zn}$. Glass coverslips $(22 \times 22 \mathrm{~mm}$; Thermo Fischer Scientific, Waltham, MA) were coated with $0.5 \mathrm{~mL}$ of nanoparticle formulation and dried in a laminar flow hood for $4 \mathrm{~h}$. The photocatalytic activity was tested on Xanthomonas sp. strain Xr-1 isolated from Rosa 'Noare' in Quincy, FL. The bacterial strain stored in $30 \%$ glycerol at $-80^{\circ} \mathrm{C}$ was plated on Yeast Nutrient Agar (YNA) culture plates and incubated at $28{ }^{\circ} \mathrm{C}$ for $48 \mathrm{~h}$. One pure colony of the strain was picked from YNA and re-plated on YNA and incubated at $28^{\circ} \mathrm{C}$ for $48 \mathrm{~h}$. Two to three pure colonies on YNA were then transferred to $10 \mathrm{~mL}$ of sterile distilled water $\left(\mathrm{dH}_{2} \mathrm{O}\right)$ in a test tube, vortexed for $10 \mathrm{~s}$, and adjusted spectrophotometrically to an optical density at $600 \mathrm{~nm}=$ 0.3 corresponding to $10^{8}$ colony-forming units $(\mathrm{CFU}) / \mathrm{mL}$. One hundred microliters of the bacterial solution were applied to the glass coverslips coated with the nanoparticle formulation.

The glass coverslips were placed under an incandescent lamp (Cheyenne Portable Lamp with $60-\mathrm{W}$ incandescent bulb; General Electric, Fairfield, CT) for photocatalytic reaction (Kau et al., 2009; Wong et al., 2006). A light meter (Model 407026; Extech Instruments, Nashua, NH) was used to measure the illumination density at the coverslips. In the photocatalytic experiment, illumination was carried out for 5,10 , and $15 \mathrm{~min}$ at $5-\mathrm{cm}$ distance from the sample, which corresponds to an illumination density of $3 \times 10^{4}$ lux (lumen $/ \mathrm{m}^{2}$ ). Illuminations were carried out at $4{ }^{\circ} \mathrm{C}$ to avoid overheating of the samples during the period of the experiment, thus avoiding an external factor that may influence cell viability. Samples were also placed in dark for $15 \mathrm{~min}$ as a control to test for a photocatalytic effect. Glass coverslips not coated with the nanoparticles were used as controls in each treatment and in each experiment. Each treatment had three glass slides, and the whole experiment was repeated once with two glass slides per treatment. After illumination, the glass coverslips were placed in sterile $50-\mathrm{mL}$ centrifuge tubes (Thermo Fischer Scientific, Waltham, MA). One milliliter of sterile $\mathrm{dH}_{2} \mathrm{O}$ was added to the tube and vortexed for $20 \mathrm{~s}$ for recovery of bacterial cells. The bacterial enumeration was determined by the standard plating method. One hundred microliters of the sample were taken to initiate a 10 -fold dilution series $\left(10^{-1}\right.$ to $10^{-7}$ ), and $100 \mu \mathrm{L}$ of each dilution were spread on YNA and incubated at $28{ }^{\circ} \mathrm{C}$ for $48 \mathrm{~h}$ after which colony counts were made.

Open-field pot experiments. The effect of nanoparticle formulation on bacterial leaf spot severity was studied on a susceptible rose cultivar, Noare (Flower Carpet ${ }^{\circledR}$ Red). There were three 2-gallon pots per plot per treatment and one-pot size width between pots and a three-pot size width between treatments. Each treatment was replicated three times. The potting substrate was pine bark, sphagnum peat, and sand $(80: 10: 10$, by volume) amended with $15 \mathrm{lbs} / \mathrm{cu}$ yd of $13 \mathrm{~N}-$ 2.6P-5K sludge fertilizer (Graco Fertilizer Company, Cairo, GA). The field studies were set up in a randomized complete block design. $\mathrm{TiO}_{2} / \mathrm{Zn}$ nanoparticle formulation was added to tap water at $1: 10(\approx 500$ to $800 \mathrm{ppm}$ $\mathrm{TiO}_{2} / \mathrm{Zn}$ ), 1:25, and 1:50 dilutions. The plants were sprayed with $\mathrm{TiO}_{2} / \mathrm{Zn}$ until runoff from leaves using a single-nozzle backpack sprayer. The ornamental industry standard was used as a control (Table 1), and untreated pots were included as another control. Four open-field pot experiments were conducted in Spring and Fall 2011 at the University of

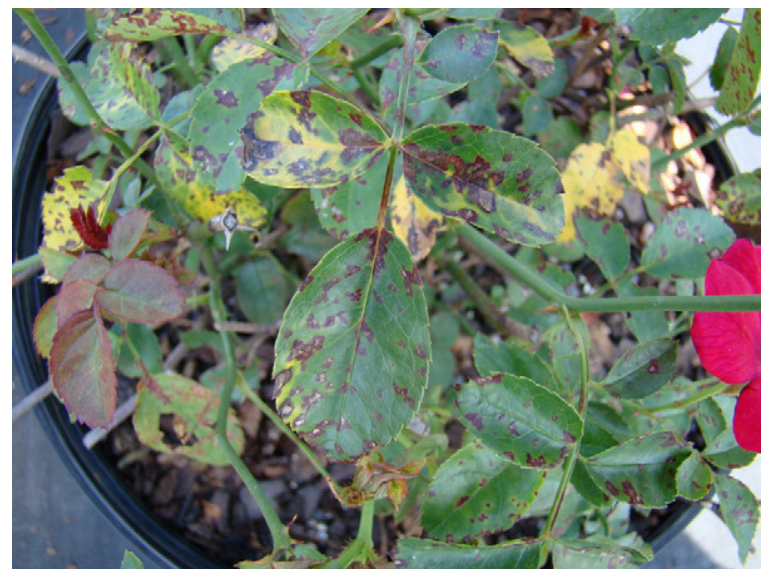

Fig. 1. Symptoms of bacterial leaf spot on rose caused by Xanthomonas sp. strain Xr-1.

Table 1. Effect of titanium dioxide/zinc $\left(\mathrm{TiO}_{2} / \mathrm{Zn}\right)$ on the incidence of bacterial leaf spot caused by Xanthomonas sp. on rose cultivar Noare (Flower Carpet ${ }^{\circledR}$ Red), shown as average area under the disease progress curve (AUDPC). ${ }^{\mathrm{z}}$

\begin{tabular}{|c|c|c|c|}
\hline \multirow[b]{2}{*}{ Treatment } & \multirow[b]{2}{*}{ Dilution $^{\mathrm{y}}$} & \multicolumn{2}{|c|}{$\mathrm{AUDPC}^{\mathrm{x}}$} \\
\hline & & Homestead, FL & Quincy, FL \\
\hline \multirow[t]{3}{*}{$\mathrm{TiO}_{2} / \mathrm{Zn}$ (7-d spray schedule) } & $1: 10$ & $335.8 \mathrm{~b}^{\mathrm{w}}$ & $247.3 \mathrm{ab}$ \\
\hline & $1: 25$ & $260.2 \mathrm{~b}$ & $177.5 \mathrm{~b}$ \\
\hline & $1: 50$ & $255.3 \mathrm{~b}$ & $232.6 \mathrm{ab}$ \\
\hline $\begin{array}{l}\text { Ornamental industry standard } \\
\text { (7-d spray schedule) }\end{array}$ & & $431.1 \mathrm{~b}$ & $276.5 \mathrm{a}$ \\
\hline Untreated & & $877.1 \mathrm{a}$ & $301.4 \mathrm{a}$ \\
\hline
\end{tabular}

${ }^{\mathrm{z} T h e}$ trials were conducted at Homestead and Quincy, FL, during Spring 2011.

${ }^{y}$ Represents the diluted formulation of $\mathrm{TiO}_{2} / \mathrm{Zn}$ (5000 to $8000 \mathrm{ppm} \mathrm{TiO}_{2}$ and 50 to $75 \mathrm{ppm} \mathrm{Zn}$ ).

${ }^{\mathrm{x}}$ Disease severities were rated using the Horsfall-Barratt scale, a non-dimensional 12-point scale, to assess the percentage of canopy affected by bacterial spot. Values were converted to midpercentages and used to generate AUDPC.

${ }^{\text {w}}$ Column means indicated with the same letters are not significantly different $(P \leq 0.05)$ based on Student Newman Keuls test.

${ }^{v}$ Ornamental industry standard spray program for management of diseases on roses (7-d spray schedule) given in the order of rotation. Heritage ${ }^{\circledR}$ (azoxystrobin; $4 \mathrm{oz} / 100 \mathrm{gal} \mathrm{H}_{2} \mathrm{O}$ ); Dithane-75 DF ${ }^{\circledR}$ (mancozeb; 24 $\mathrm{oz} / 100 \mathrm{gal} \mathrm{H}_{2} \mathrm{O}$ ); T-Methyl [thiophanate-methyl; $20 \mathrm{oz} / 100$ gal $\mathrm{H}_{2} \mathrm{O}$; CuPro (copper hydroxide; $16 \mathrm{oz} / 100$ gal $\left.\mathrm{H}_{2} \mathrm{O}\right)$ ]. 
Newman Keuls test. The analysis was performed with SAS (SAS Version 9.1; SAS Institute Inc., Cary, NC).

\section{Results}

Photocatalytic activity of $\mathrm{TiO}_{2} / \mathrm{Zn}$ nanoparticle formulation on Xanthomonas $s p$. $\mathrm{TiO}_{2} / \mathrm{Zn}$-coated glass coverslips significantly reduced survival of Xanthomonas sp. strain $\mathrm{Xr}-1$ to $\approx 3$ to $4 \log \mathrm{CFU} / \mathrm{mL}$ within 10 min of photocatalysis compared with noncoated and non-illuminated controls, which had bacterial populations in the range of 6 to $7 \log$ CFU/mL (Fig. 2). At $15 \mathrm{~min}$, a bacterial population of less than $1 \log \mathrm{CFU} / \mathrm{mL}$ was recovered from $\mathrm{TiO}_{2} / \mathrm{Zn}$ glass coverslips. There was no significant reduction in the number of viable bacteria on non-coated glass coverslips in the illuminated condition compared with coated and non-coated glass coverslips under the non-illuminated condition at any time period.

Bacterial leaf spot severity on roses treated with $\mathrm{TiO}_{2} / \mathrm{Zn}$ nanoparticles. Application of $\mathrm{TiO}_{2} / \mathrm{Zn}$ significantly reduced bacterial leaf spot severity compared with the untreated control in all trials and was better or on par with the ornamental nursery practice, although activity did not consistently correlate with the dilution rates (Tables 1 and 2). In the Spring 2011 trial at Homestead, $\mathrm{TiO}_{2} / \mathrm{Zn}$ treatments at $1: 10(\approx 500$ to $800 \mathrm{ppm}), 1: 25$, and 1:50 dilutions had the lowest disease severity and was significantly lower $(62 \%$ to $71 \%$ ) than the untreated control (Table 1). The industry standard had higher disease severity than all the $\mathrm{TiO}_{2} / \mathrm{Zn}$ treatments, but this was not statistically different $(P \leq 0.05)$. The trial at Quincy in Spring 2011 had lower disease pressure than the trial at Homestead conducted during the same time of the year (Table 1). $\mathrm{TiO}_{2} / \mathrm{Zn}$ treatment at 1:25 dilution had the lowest disease severity but was not statistically different from 1:10 and 1:50 dilutions. Disease severity in plants with $\mathrm{TiO}_{2} / \mathrm{Zn}$ treatment at 1:25 dilution was significantly lower than the industry standard by $36 \%$ and the untreated control by $41 \%$. In the Fall 2011 trial at Homestead, all $\mathrm{TiO}_{2} / \mathrm{Zn}$ treatments had significantly lower disease severity compared with the untreated control (Table 2). Bacterial leaf spot severity of plants treated with 1:10 dilution of $\mathrm{TiO}_{2} / \mathrm{Zn}$ was significantly lower than the industry standard by $48 \%$ and untreated control by $70 \%$. There was no statistical difference in the disease severity between the 1:10 dilution of $\mathrm{TiO}_{2} / \mathrm{Zn}$ and the ornamental industry standard in the Cairo trial. However, disease severity was significantly lower compared with untreated control by $33 \%$. Although disease severity on plants treated with $\mathrm{TiO}_{2} / \mathrm{Zn}$ at 1:25 and 1:50 dilutions was lower than the industry standard in both fall trials, it was not statistically different. There was no statistically significant difference in disease severity between the $\mathrm{TiO}_{2} / \mathrm{Zn}$ treatments in these trials.

\section{Discussion}

The work we report here illustrates the potential of photocatalytic materials to reduce the impact of bacterial leaf spot on roses. The past few decades of research on photocatalysis has well documented that the interaction of energetic photons with an appropriate mineral catalyst like $\mathrm{TiO}_{2}$ creates chemically reactive oxygen species that destroy organic molecules, damaging microbes proximal to such photocatalytic materials sufficient to reduce their viability (Page et al., 2009). As demonstrated by our results, photocatalysis leads to cell death of Xanthomonas sp., thus reducing bacterial leaf spot severity. $\mathrm{TiO}_{2} / \mathrm{Zn}$ did not leave any visible residue on the leaves in this study, hence making it more suitable commercially than macroparticulate $\mathrm{TiO}_{2}$ that is known to leave a visible residue (Norman and Chen, 2011). Unlike many other biocides, the novelty of this approach is that the material is constantly activated in the presence of sunlight making it more durable; thus, longer intervals between applications may be feasible. $\mathrm{TiO}_{2}$ occurs naturally in soil and a highly purified form has been used in many commercial products over decades and is classified as non-toxic (EPA, 2005; FDA, 2012). The advent of nanoparticles for commercial use has in recent years triggered many studies on the fate of $\mathrm{TiO}_{2}$ nanoparticles in the environment that are summarized in several comprehensive reviews (EPA, 2009, 2010a, 2010b). However, formal studies of the safety of nanoparticles for agricultural use are currently lacking as a result of the novelty of this approach (Gogos et al., 2012). Consideration of the formal regulatory status of nanoscale materials as a group generally is ongoing, although the U.S. Environmental Protection Agency (EPA) indicated its intent to continue to not regard particle size as a key distinguishing characteristic under the Toxic Substances Control Act for entities having the same molecular structure (EPA, 2008, 2009). The U.S. EPA classifies $\mathrm{Zn}$ as a minimal-risk pesticide and it is exempt from registration. Zinc does have biologic activity, but the risks from this agent are relatively low. The total $\mathrm{Zn}$ arising from the eight applications described is in the very low tens of grams per acre.

Although $\mathrm{TiO}_{2} / \mathrm{Zn}$ showed antibacterial properties in all of our trials, a consistent dose response to the severity of bacterial leaf spot was not seen in two of the four trials with 1:25 dilution performing better than 1:10 dilution. This may be the result of the removal of $\mathrm{TiO}_{2} / \mathrm{Zn}$ from the leaf surfaces during rain events or overhead irrigation as a result of

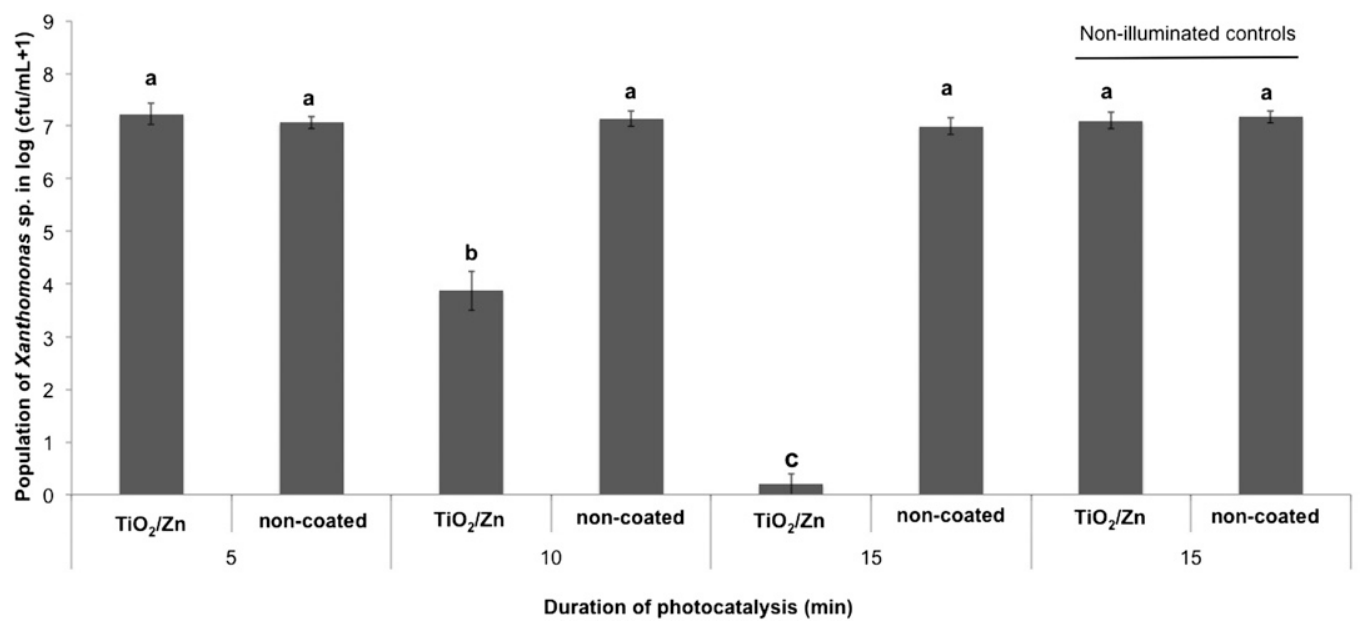

Fig. 2. Photocatalytic activity of a titanium dioxide/zinc $\left(\mathrm{TiO}_{2} / \mathrm{Zn}\right)$ nanoparticle formulation on Xanthomonas sp. strain Xr-1 causing bacterial leaf spot on rose. The nanoparticles coated on glass coverslips were exposed to visible light illumination for 5,10 , and 15 min at $4{ }^{\circ} \mathrm{C}$. Illumination was carried out at a light density of $3 \times 10^{4}$ lux (lumen $\left./ \mathrm{m}^{2}\right)$. Non-coated represents glass coverslips not coated with the nanoparticles. Non-illuminated represents experiments conducted in the dark without illumination. For all the experiments, under each illumination condition, the percentages of the surviving bacteria were determined by the standard plating method. Each treatment had three replications, and the entire experiment was repeated with two replications per treatment. Means followed by the same letter are not significantly different at $P \leq 0.05$ based on Student Newman Keuls test (SNK). The error bar represents the SEM. 
Table 2. Effect of titanium dioxide/zinc $\left(\mathrm{TiO}_{2} / \mathrm{Zn}\right)$ on the incidence of bacterial leaf spot caused by Xanthomonas sp. on rose cultivar Noare (Flower Carpet ${ }^{\circledR}$ Red), shown as average area under the disease progress curve (AUDPC). ${ }^{\mathrm{z}}$

\begin{tabular}{|c|c|c|c|}
\hline \multirow[b]{2}{*}{ Treatment } & \multirow[b]{2}{*}{ Dilution $^{\mathrm{y}}$} & \multicolumn{2}{|c|}{ AUDPC $^{\mathrm{x}}$} \\
\hline & & Homestead, FL & Cairo, GA \\
\hline $\mathrm{TiO}_{2} / \mathrm{Zn}$ (7-d spray schedule) & $1: 10$ & $231.0 \mathrm{c}^{\mathrm{W}}$ & $561.2 \mathrm{~b}$ \\
\hline & $1: 25$ & $293.4 \mathrm{bc}$ & $663.8 \mathrm{ab}$ \\
\hline & $1: 50$ & $358.8 \mathrm{bc}$ & $656.8 \mathrm{ab}$ \\
\hline $\begin{array}{l}\text { Ornamental industry standard } \\
\text { (7-d spray schedule) }\end{array}$ & & $443.3 \mathrm{~b}$ & $693.0 \mathrm{ab}$ \\
\hline Untreated & & $767.1 \mathrm{a}$ & $842.9 \mathrm{a}$ \\
\hline
\end{tabular}

zThe trials were conducted at Homestead, FL, and Cairo, GA, during Fall 2011.

${ }^{y}$ Represents the diluted formulation of $\mathrm{TiO}_{2} / \mathrm{Zn}\left(5000\right.$ to $8000 \mathrm{ppm} \mathrm{TiO}_{2}$ and 50 to $\left.75 \mathrm{ppm} \mathrm{Zn}\right)$.

${ }^{x}$ Disease severities were rated using the Horsfall-Barratt scale, a non-dimensional 12-point scale, to assess the percentage of canopy affected by bacterial leaf spot. Values were converted to midpercentages and used to generate AUDPC.

${ }^{\mathrm{w}}$ Column means indicated with the same letters are not significantly different $(P \leq 0.05)$ based on Student Newman Keuls test.

'Ornamental industry standard spray program for management of diseases on roses (7-d spray schedule) given in the order of rotation. Heritage ${ }^{\circledR}$ (azoxystrobin; 4 oz/100 gal H $\mathrm{H}_{2} \mathrm{O}$ ); Dithane-75 DF ${ }^{\circledR}$ (mancozeb; $24 \mathrm{oz} / 100$ gal $\mathrm{H}_{2} \mathrm{O}$ ); T-Methyl [thiophanate-methyl; $20 \mathrm{oz} / 100$ gal $\mathrm{H}_{2} \mathrm{O}$; CuPro (copper hydroxide; $16 \mathrm{oz} / 100$ gal $\left.\left.\mathrm{H}_{2} \mathrm{O}\right)\right]$.

the absence of any stickers in the formulated materials as well as in the treatment. Incorporation of stickers into the formulation in future studies may be necessary to avoid $\mathrm{TiO}_{2} / \mathrm{Zn}$ runoff from leaves. During our Fall 2011 in Cairo, we noticed partial leaf phytotoxicity ( $\approx 5 \%$ to $10 \%$ leaf area) after the seventh spray. This is likely the result of the deposition of too much photocatalytic material on the leaf surface of plants over multiple applications using a conventional sprayer. We noticed a similar issue in our studies on tomato, which was resolved by the use of an electrostatic sprayer for application of the nanoparticles and resulted in no phytotoxicity in tomato (unpublished data). We hypothesize the electrostatic sprayer applies particles that are more evenly distributed on the plant surface thereby limiting the chances of phytotoxicity compared with accumulation of the nanoparticles at single points on plant surfaces when a conventional sprayer is used. The volume of material delivered to leaf surfaces using an electrostatic sprayer is significantly lower (less than $60 \%$ to $75 \%$ ) compared with that of a conventional sprayer. This may be another reason for no phytotoxicity with an electrostatic sprayer.

Evaluating photocatalytic nanoscale formulations of $\mathrm{TiO}_{2} / \mathrm{Zn}$ for bacterial leaf spot management is a new approach for disease management on roses. The findings from this study are expected to lead us to further testing of many photocatalytic materials with high antibacterial properties including materials other than $\mathrm{Zn}$ in the $\mathrm{TiO}_{2}$ nanoparticle structure. Studies on spray regimes and maximum sprays required for effective disease management are currently underway. A key aspect in the future commercialization of a nanoparticle technology will be the cost-effectiveness of using the material compared with other materials available in the market. The study presented here is the first testing of the technology on roses and its possibilities in disease management. Further improvisations of the material for higher antibacterial properties are in progress. Based on these studies, a cost-effectiveness analysis will be conducted. In addition, studies on an integrated management strategy using SAR inducers are in progress.

\section{Literature Cited}

Adams, L.K., D.Y. Lyon, and P.J.J. Alvarez. 2006. Comparative eco-toxicity of nanoscale $\mathrm{TiO}_{2}$, $\mathrm{SiO}_{2}$, and $\mathrm{ZnO}$ water suspensions. Water Res. 40:3527-3532.

Anpo, M. 2000. Utilization of $\mathrm{TiO}_{2}$ photocatalysts in green chemistry. Pure Appl. Chem. 72: $1265-1270$.

Canteros, B. 2002. Control of citrus canker caused by strains of Xanthomonas axonopodis pv. citri thology 92:S116 [Meeting abstract].

Chen, X. and S.S. Mao. 2007. Titanium dioxide nanomaterials: Synthesis, properties, modifications, and applications. Chem. Rev. 107:28912959.

Choi, J.Y., C.J. Chung, K.T. Oh, Y.J. Choi, and K.H. Kim. 2009. Photocatalytic antibacterial effect of $\mathrm{TiO}_{2}$ film of TiAg on Streptococcus mutans. Angle Orthod. 79:528-532.

Colon, G., M. Maicu, M.C. Hidalgo, and J.A. Navio. 2006. Cu-doped $\mathrm{TiO}_{2}$ systems with improved photocatalytic activity. Appl. Catal. B 67:41-51.

Dancer, S.J. 2008. Importance of the environment in methicillin-resistant Staphylococcus aureus acquisition: The case for hospital cleaning. Lancet Infect. Dis. 8:101-113.

EPA. 2005. 40CFR-180.920 \& 40CFR-180-930. general approach. 12 Dec. 2012. <http://www. epa.gov/oppt/nano/nmsp-inventorypaper2008. pdf $>$.

EPA. 2009. Nanoscale materials stewardship program, interim report. 12 Dec. 2012. <http://epa. gov/oppt/nano/nmsp-interim-report-final.pdf $>$.

EPA. 2010a. State of the Science literature review; Nano titanium dioxide environmental matters, EPA/600/R-10/089.

EPA. 2010b. Nanomaterial case studies; Nanoscale titanium dioxide in water treatment and in topical sunscreen, EPA/600/R-09/057F.

FDA. 2012. Listing of color additives exempt from registration. 21CFR73.575.

Gogos, A., K. Knauer, and T.D. Bucheli. 2012. Nanomaterials in plant protection and fertilization: Current state, foreseen applications, and susceptible and resistant to copper. Phytopa-

EPA. 2008. TSCA inventory of nanoscale substances - research priorities. J. Agr. Food Chem. 60: 9781-9792.

Horsfall, J.G. and R.W. Barratt. 1945. An improved grading system for measuring plant disease. Phytopathology 35:655.220.

Kau, J.-H., D.-S. Sun, H.-H. Huang, M.-S. Wong, H.-C. Lin, and H.-H. Chang. 2009. Role of visible light-activated photocatalyst on the reduction of anthrax spore-induced mortality in mice. PLoS ONE 4:E4167.

Lu, J.W., F.B. Li, T. Guo, L.W. Lin, M.F. Hou, and T.X. Liu. 2006. $\mathrm{TiO}_{2}$ photocatalytic antifungal technique for crops diseases control. J. Environ. Sci. (China) 18:397-401.

Matsunaga, T., R. Tomoda, T. Nakajima, and H. Wake. 1985. Photoelectrochemical sterilization of microbial-cells by semiconductor powders. FEMS Microbiol. Lett. 1985:211-214.

Namiki, N., K. Cho, P. Fraundorf, and P. Biswas. 2005. Tubular reactor synthesis of doped nanostructured titanium dioxide and its enhanced activation by coronas and soft $\mathrm{x}$-rays. Ind. Eng. Chem. Res. 44:5213-5220.

NASS. 2012. United States Department of Agriculture. Floriculture crops 2011 summary. 12 Dec. 2012.<http://usda01.library.cornell.edu/usda/ current/FlorCrop/FlorCrop-05-31-2012.pdf >

Norman, D.J. and J. Chen. 2011. Effect of foliar application of titanium dioxide on bacterial blight of geranium and Xanthomonas leaf spot of poinsettia. HortScience 46:426-428.

Owolade, O.F. and D.O. Ogunleti. 2008. Effects of titanium dioxide on the diseases, development and yield of edible cowpea. J. Plant Prot. Res. 48:329-335.

Page, K., M. Wilson, and I.P. Parkin. 2009. Antimicrobial surfaces and their potential in reducing the role of the inanimate environment in the incidence of hospital-acquired infections. J. Mater. Chem. 19:3819-3831.

Pernezny, K., R. Nagata, K. Havranek, and J. Sanchez. 2008. Comparison of two culture media for determination of the copper resistance of Xanthomonas strains and their usefulness for prediction of control with copper bactericides. Crop Prot. 27:256-262.

Ritchie, D.F. and U. Dittapongpitch. 1991. Copperand-streptomycin resistant strains and hostdifferentiated races of Xanthomonas campestris pv. vesicatoria in North Carolina. Plant Dis. 75:733-736.

Tsuang, Y.H., J.S. Sun, Y.C. Huang, C.H. Lu, W.H.S. Chang, and C.C. Wang. 2008. Studies on photokilling of bacteria using titanium dioxide nanoparticles. Artif. Organs 32:167174.

USDA. 2010. Census of horticultural specialties. 12 Dec. 2012.<http://www.agcensus.usda.gov/ Publications/2007/Online_Highlights/Census_ of_Horticulture_Specialties/HORTIC.pdf $>$.

Vallad, G.E. 2009. Effect of acibenzolar-S-methyl on bacterial leaf spot of shrub roses caused by a Xanthomonas sp. APS Caribbean Meeting abstracts, 16-19 May 2009, Orlando, Florida. 12 Dec. 2012. <http://www.apsnet. org/members/divisions/carib/meetings/Pages/ CaribbeanMeetingAbstracts2009.aspx $>$.

Wong, M.-S., W.-C. Chu, D.-S. Sun, H.-S. Huang, J.H. Chen, P.-J. Tsai, N.-T. Lin, M.-S. Yu, S.-F. Hsu, S.-L. Wang, and H.-H. Chang. 2006. Visible-light-induced bactericidal activity of a nitrogen-doped titanium photocatalyst against human pathogens. Appl. Environ. Microbiol. 72:6111-6116.

Wu, B., R. Huang, M. Sahu, X. Feng, P. Biswas, and Y.J. Tang. 2010. Bacterial responses to $\mathrm{Cu}$ doped $\mathrm{TiO}_{2}$ nanoparticles. Sci. Total Environ. 408:1755-1758. 